\title{
GENUS OCTACANTHIUM (ZYGNEMAPHYCEAE, DESMIDIACEAE) IN THE STATE OF SÃO PAULO, BRAZIL
}

\author{
Sílvia Maria Mathes Faustino ${ }^{1}$ \& Carlos E. de M. Bicudo ${ }^{2}$
}

\author{
Biota Neotropica v3 (n1) - http://www.biotaneotropica.org.br/v3n1/pt/abstract?article+BN00303012003 \\ Date Received 01/05/2003 \\ Revised $02 / 15 / 2003$ \\ Accepted 03/07/2003
}

\author{
${ }^{1}$ Graduate student in the Programa de Pós-graduação em Biologia Comparada, \\ Faculdade de Filosofia, Ciências e Letras de Ribeirão Preto, Universidade de São Paulo, \\ Av. Bandeirantes, 3900, 14040-900 Ribeirão Preto, SP, Brasil \\ E-mail: fitomathes@yahoo.com \\ ${ }^{2}$ Seção de Ecologia, Instituto de Botânica, Caixa postal 4005, \\ 01061-970 São Paulo, SP, Brasil \\ E-mail: cbicudo@terra.com.br
}

\begin{abstract}
A floristic survey was based on the study of 148 sample units, from which 75 were already deposited at the Herbário Científico do Estado "Maria Eneyda P. Kauffmann Fidalgo" of the Instituto de Botânica, São Paulo State Department of Environment, and 73 were collected during the period 2000-2001. Three taxa of Octacanthium (Desmidiales, Zygnemaphyceae) were identified: O. bifidum (Brébisson) Compère var. bifidum, O. mucronulatum (Nordstedt) Compère var. mucronulatum, and O. octocorne (Ralfs) Compère var. octocorne.
\end{abstract}

Key words: Taxonomy, floristic survey, biodiversity, algae, Brazil.

\section{Resumo}

O levantamento florístico foi baseado em 148 unidades amostrais, das quais 75 já se encontravam depositadas no Herbário Científico do Estado "Maria Eneyda P. Kauffmann Fidalgo" do Instituto de São Paulo, Secretaria do Meio Ambiente do Estado de São Paulo e 73 foram coletadas durante no período 2000-2001. Três táxons de Octacanthium (Desmidiales, Zygnemaphyceae) foram identificados: O. bifidum (Brébisson) Compère var. bifidum, O. mucronulatum (Nordstedt) Compère var. mucronulatum e O. ocotocorne (Ralfs) Compère var. octocorne.

Palavras-chave:Taxonomia, levantamento florístico, biodiversidade, algas, Brasil. 


\section{INTRODUCTION}

The genus Octacanthium was proposed by Compère (1996) to include all species formerly classified in the Sect. Octacanthium of genus Arthrodesmus. It presently includes nine worldwide known species.

First report of the occurrence of representatives of this genus in Brazil is in Nordstedt (1869). Octacanthium mucronulatum (Nordst.) Comp. (as Arthrodesmus mucronulatus Nordst.) is the only species cited in that paper, based on material collected in the municipality of Lagoa Santa, state of Minas Gerais. Notice above was accompanied by a brief description and illustration of the material studied.

All knowledge of Octacanthium for the state of São Paulo is in just two papers. Borge (1918) was the first to refer to the genus for the state of São Paulo. The paper was based on material collected by Alberto Löfgren in the municipality of Pirassununga, and just $O$. octocorne (Ralfs) Comp. (as Arthrodesmus octocornis Ralfs) was cited.

In 1977, Bicudo and Azevedo published the first volume of the São Paulo state desmid flora ("Desmidioflórula paulista"), in which there is reference to three species of Octacanthium, namely O. bifidum (Bréb.) Comp. var. bifidum (as Arthrodesmus bifidus Bréb. var. bifidus), O. mucronulatum (Nordst.) Comp. var. mucronulatum (as Arthrodesmus mucronulatus Nordst. var. mucronulatus), and O. octocorne (Ralfs) Comp. (as Arthrodesmus octocornis Ehr. ex Arch. var. octocornis). All three species were illustrated and fully discussed in their morphology (Bicudo \& Azevedo, 1977).

The state of São Paulo's geographical area covered by the two papers above is very restricted, representing less than $10 \%$ of that of the state. Furthermore, there has never been a publication prior to the present paper that presented such a detailed genus inventory, considering the state of São Paulo's geographical area. In conclusion, in both the size of the geographical area now covered, as well as the scientific depth of the taxonomical treatment, present research provides new information.

\section{MATERIAL AND METHODS}

The study area is that of the state of São Paulo (Fig. 1).

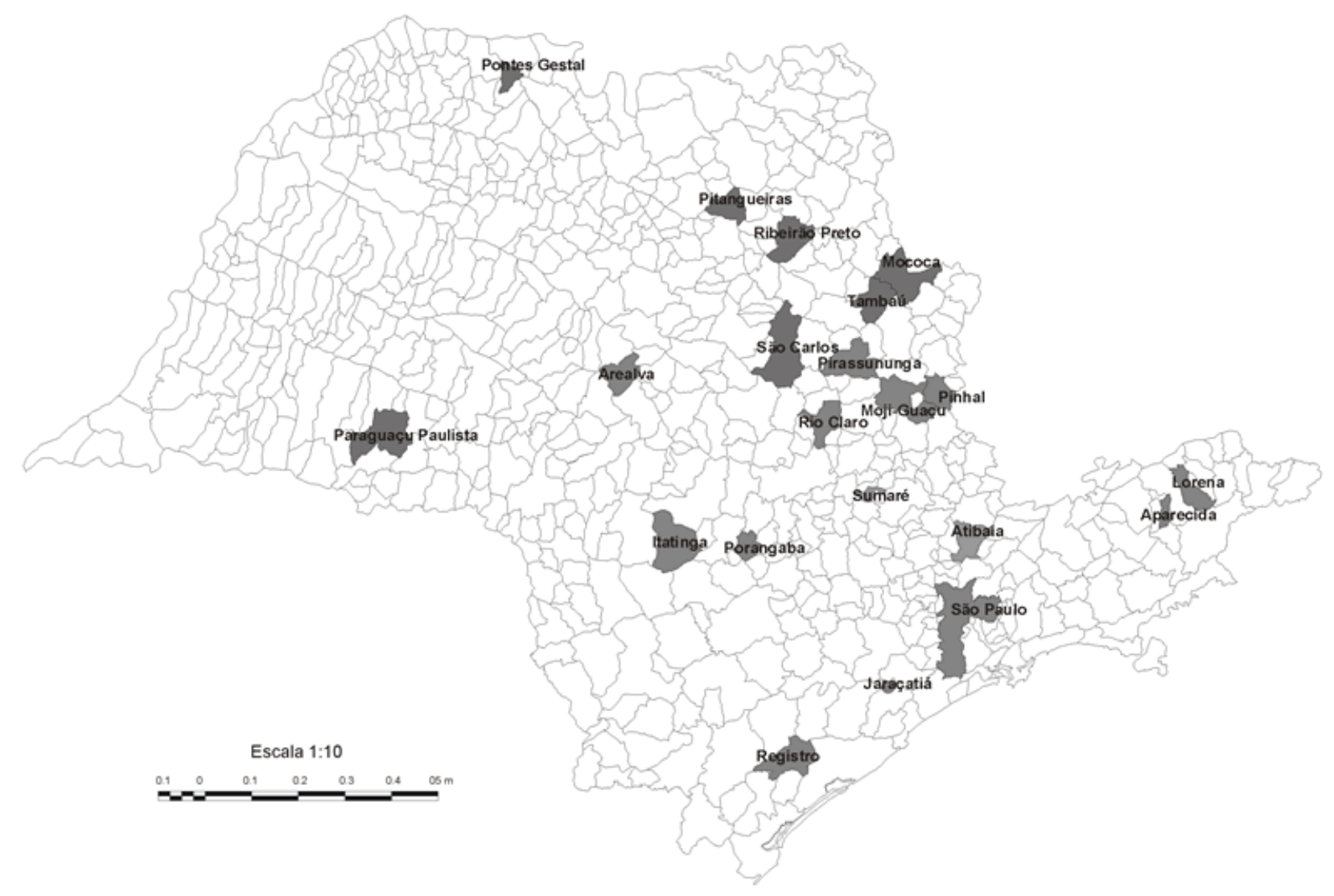

Fig1. Map of the state of São Paulo showing municipalities wich Octacanthium specimens were collected

http://www.biotaneotropica.org.br 
Description of taxa and synonyms presently considered specifically refer to the São Paulo State material.

One hundred and forty eight sample units were studied, which were collected from 110 localities in the state of São Paulo. Below are the 8 sample units in which representatives of Octacanthium were found, listed according to increasing access to the herbarium code numbers.

SP188207: Municipality of Porangaba, intersection of roads SP-162 and SP-141, right side, direction of Porangaba, swampy area with Gramineae, Cyperaceae, and Typha, col. A.A.J. de Castro \& C.E.M. Bicudo, 17-XI-1988.

SP188219: Municipality of Rio Claro, Horto Florestal "Navarro de Andrade", pond with Eichhornia and Nymphaea, col. A.A.J. de Castro \& C.E.M. Bicudo, 17-VII1989.

SP239097: Municipality of São Paulo, Luísa and Oscar Americano Foundation, artificial tank, with abundant growth of Spirodela and Salvinia, col. A.A.J. de Castro \& D.C. Bicudo, 08-XI-1991.

SP336343: Municipality of Pitangueiras, SP-322, km 368, reservoir, with Nymphaea elegans, squeezing of Salvinia (periphyton), col. C.E.M. Bicudo, S.M.M. Faustino \& L.L. Morandi, 16-VIII-2000.

SP336344: Municipality of Pitangueiras, SP-322, km 368, reservoir, with Nymphaea elegans, squeezing of Salvinia (periphyton), col. C.E.M. Bicudo, S.M.M. Faustino \& L.L. Morandi, 16-VIII-2000.

SP336345: Municipality of Pitangueiras, SP-322, km 368, reservoir, with Nymphaea elegans, squeezing of Salvinia (periphyton), col. C.E.M. Bicudo, S.M.M. Faustino \& L.L. Morandi, 16-VIII-2000.

SP336347: Municipality of Itatinga, intersection of roads "Elesbão Gutierres" and SP-280, main entrance to Itatinga, river, periphyton, col. L.L. Morandi \& S.P. Schetty, 21-IX-2000.

SP336350: Municipality of Paraguaçu Paulista, SP-421, km 58, reservoir, with Utricularia and Nitella (Estância Riacho Doce), periphyton collected with plankton net, col. C.E.M. Bicudo, L.A. Carneiro \& S.M.M. Faustino, 28-III-2001.

Sampling of plankton material was performed by using a $20 \mu \mathrm{m}$ mesh nylon plankton net. Net was used as many times in the system's superficial layer ( $\pm 30 \mathrm{~cm}$ depth), as was needed to obtain a reasonable amount of material. Measure of such a 'reasonable amount' was taken by the naked eye according to the appearance of a greenish to greenish-brown mass that accumulated at the bottom of the collecting vial. Such a slimy mass is, in general, very rich in desmid material. Samplings were carried out at the littoral zone of both lotic and lentic systems, where there are usually plenty of attached aquatic plants, totally or partially submersed, making such environments natural plankton traps.

Periphytic material was collected by manual squeezing of totally or partially submersed plants (bryophytes, pteridophytes, and phanerogams), and by the gathering of complete specimens or of submersed parts of emergent specimens.

Sample fixation and preservation was performed immediately after collection, in the field, with formaldehyde 3$5 \%$ aqueous solution. Immediate fixation aimed at preserving cell morphology as much as possible to that at the moment of collection. Concentration of material in the vial may cause acceleration of the cell division rate in certain species, especially in those of desmids and, consequently, production of many anomalous phenotypes because the alga has not got enough time to fully develop all its structures before undergoing a new division. Since apparent morphology is the basis for the sorting out of species, varieties, and taxonomic formae in Octacanthium, it is mandatory that such results of malformations be avoided and, if they occur, that they are not mistaken for regular expressions of the intra-population morphological variation spectrum.

All material studied is deposited at the Instituto de Botânica herbarium (SP). All information pertaining to the sampling localities obtained after installation of the BIOTA / FAPESP Program obligatorily followed the program's standard forms, and location of the collecting sites was defined by GPS.

\section{RESULTS AND DISCUSSION}

\section{Octacanthium (Hansgirg) Compère}

Nova Hedwigia 112: 502.1996.

Basionym: Arthrodesmus Sect. Octacanthium Hansg., Arch. Naturw. Landes-durchforsch. Böhmen 6(6): 203. 1888.

Cells solitary, constricted at the midregion, isthmus narrow; semicells elliptic to subhexagonal, with 2 or 4 spines located usually 1 , very seldom 2 at the tip of each prominent angle, when 2 in just 1 transverse plane, when 4 in 2 superimposed transverse planes; cell wall apparently smooth or clearly punctate, without facial median decoration. Chloroplasts not observed.

Type species: Octacanthium octocorne (Ralfs) Comp., Nova Hedwigia 112: 503, fig. 1-2. 1996 (=Xanthidium octocorne Ralfs, Brit. Desmidieae. 116, pl. 20, fig. 2a-e. 1848).

Genus Octacanthium was proposed by Compère (1996) who, in fact, erected to the genus level the former Sect. Octacanthium Hansg. of Arthrodesmus Ehr. ex Ralfs.

The genus name Arthrodesmus Ehr. ex Ralfs 1848 appeared for the first time in the literature in Ehrenberg (1836), in a list of synonyms, without description and/or diagnosis, as a mere etymologically advantageous synonym for 

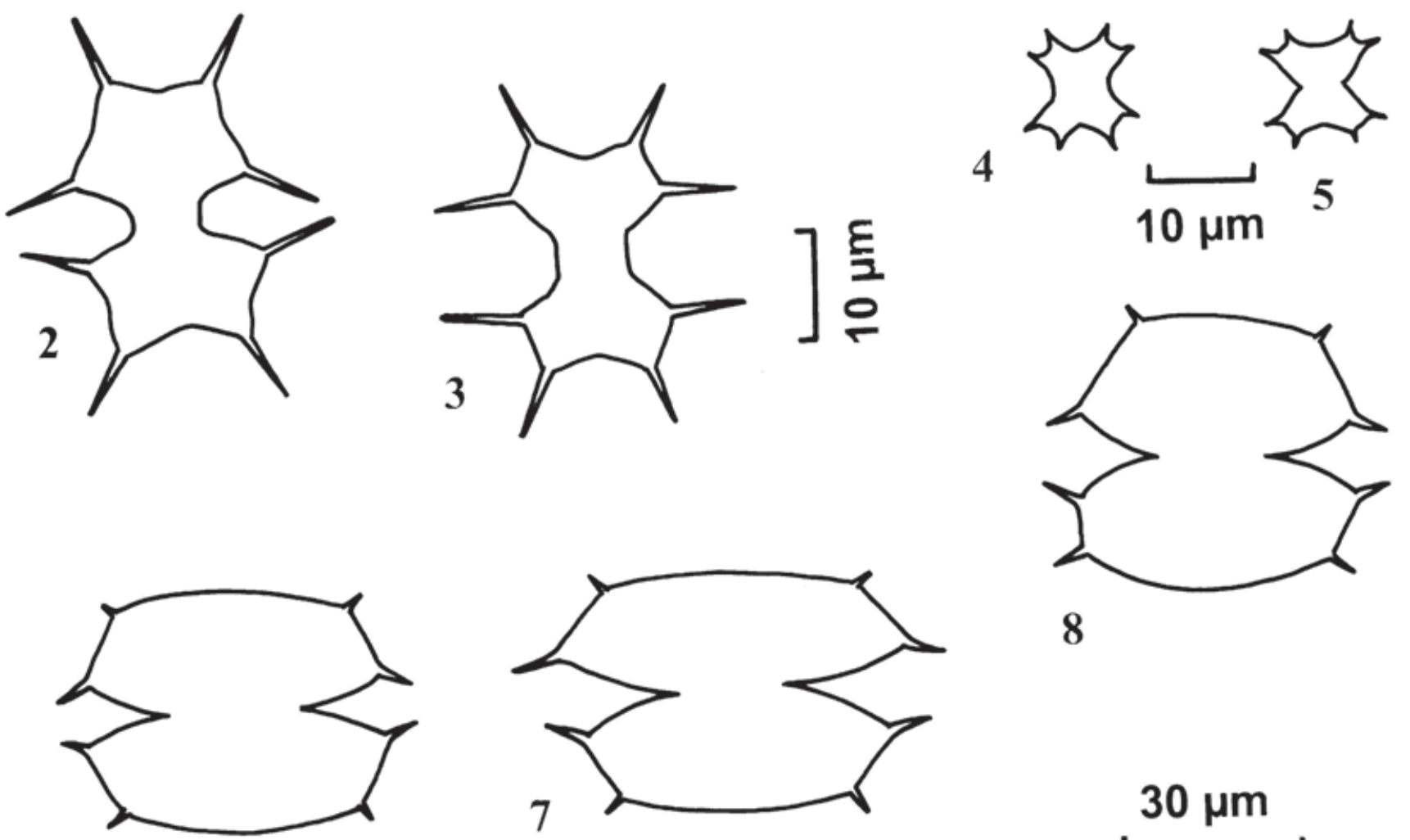

6
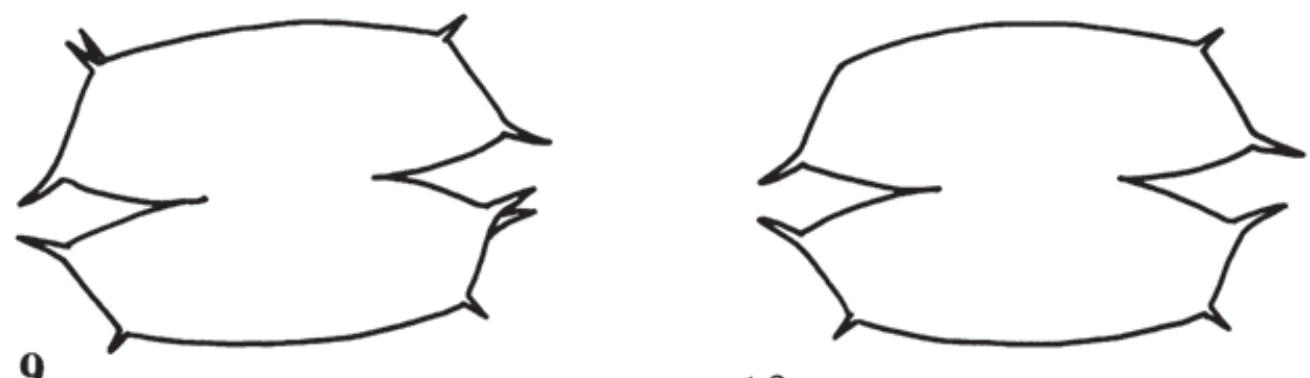

10
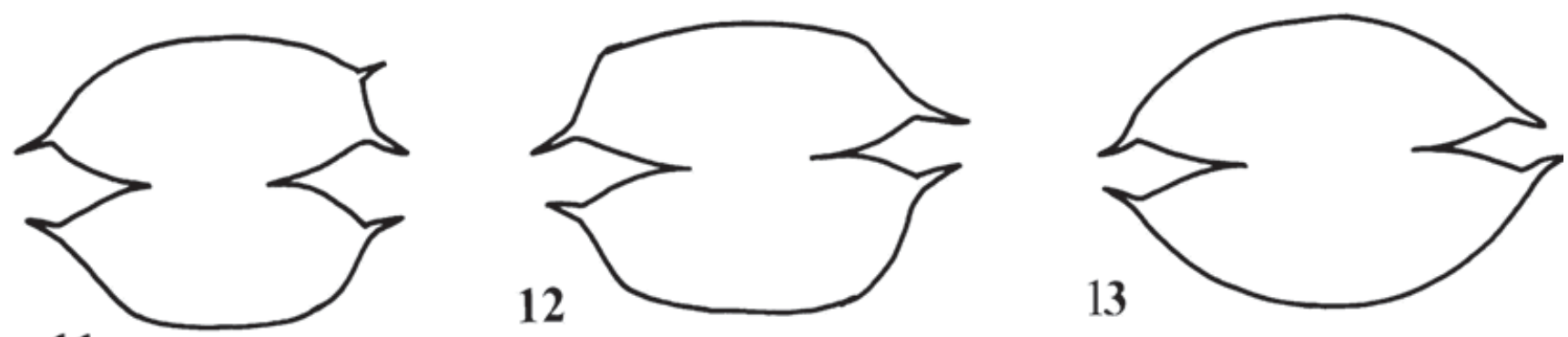

Fig. 2-3. Octacanthium octocorne (Ralfs) Comp. var. octocorne.

Fig. 4-5. Octacanthium bifidum (Ralfs) Comp. var. bifidum (de Bicudo \& Azevedo, 1977).

Fig. 6-13. Octacanthium mucronulatum (Nordst.) Comp.

http://www.biotaneotropica.org.br 
Scenedesmus Meyen 1829. The first formal description for Arthrodesmus is in Ehrenberg (1838). However, because Ralfs (1848) is the later starting point for the nomenclature of Desmidiaceae and included Arthrodesmus Ehr. 1838 among the synonyms of Arthrodesmus Ralfs, the date for the effective and valid publication of the genus name Arthrodesmus is 1848 and its authority may either be Ehrenberg 1838 ex Ralfs 1848 or simply Ralfs 1848. Anyway, Arthrodesmus Ralfs 1848 is a later homonym of Arthrodesmus Ehr. 1838 and, under this circumstance, it can no longer be used since it is an illegitimate name (Art. 53.1 of the St. Louis International Code of Botanical Nomenclature).

The genus Arthrodesmus Ehr. ex Ralfs 1848 was divided into four sections. All species classified in the Sect. Arthrodesmus, typical (= Sect. Tetracanthium Hansg.), were transferred to Staurodesmus Teil. 1948. Species of the Sect. Ornatae Bourr. ex C. Bic. \& Azev. 1977 gave rise to the genus Bourrellyodesmus Comp. The species classified in Sect. Octacanthium Hansg. and Sect. Polycanthium Printz remained under the illegitimate name Arthrodesmus Ehr. ex Ralfs 1848, and had to be accommodated in another genus. Such species that summed up nine [O. octocorne (Ralfs) Comp., O. bifidum (Bréb.) Comp., O. borgei (Thom.) Comp., O. controversum (West \& West) Comp., O.japonicum (Hir.) Comp., O. longispinum (Borge) Comp., O. mucronulatum (Nordst.) Comp., O. sachlanii (Scott \& Presc.) Comp., and O. trispinatum (West \& West) Comp.] were transferred to Octacanthium Comp. 1996.

Artificial key for identification of taxa studied:

1. Cells broader than long

..O. mисronulatum var. mисronulatum

1. Cells as long as broad or longer than broad........... ... 2

2. Cells X-shaped; isthmus extremely reduced, never subcylindrical

O. bifidum var. bifidum

2. Cells subtrapeziform to subhexagonal; isthmus elongate,subcylindrical.

O. octocorne var. octocorne

\section{Octacanthium bifidum (Brébisson) Compère var. bifidum}

Nova Hedwigia 112: 503, fig. 3. 1996.(Fig. 4-5)

Basionym: Arthrodesmus bifidus Bréb., Mém. Soc. Imp. Sci. nat. Cherbourg 4: 135, pl. 1, fig. 19. 1856.

Synonym: Xanthidium bifidum (Bréb.) Defl., Bull. Soc. bot.
Fr. 76: 137. 1929; Mar. \& Sophia, Hoehnea 24(1): 46, fig. 57. 1997.

Cells approximately as long as broad including the spines, X-shaped, moderately constricted at the mid-region; semicells lunate-elliptical to almost hexagonal, angles usually slightly curved upwards, 2-fid, emarginate, upper margin straight to slightly concave, basal margins straight to more or less convex, sinus open, somewhat rectangular; cell wall hyaline, smooth; apical view of semicell elliptical, 1 minute spine on each pole; chloroplasts axial, shape not known, 1 pyrenoid. Measurements: cell length (with spines) 22-25 $\mu \mathrm{m}$, (without spines) not measured, breadth (with spines) $38-40 \mu \mathrm{m}$, (without spines) $24-28 \mu \mathrm{m}$, breadth of isthmus $11-12 \mu \mathrm{m}$.

In literature: Moji Guaçu (Marinho \& Sophia, 1997: 46, fig. 57, as Xanthidium bifidum (Bréb.) Defl.), São Paulo (Bicudo \& Azevedo, 1977: 54, as Arthrodesmus bifidus Bréb. var. bifidus).

Present study sample units in which the species was encountered: none.

Specimens collected in the state of São Paulo came from two localities, i.e. Açude do Jacaré, a small, artificial reservoir located at the Moji Guaçu Biological Reserve, municipality of Moji Guaçu, and from a pond located between km 74 and 75 of road SP-88, municipality of São Paulo. Populations studied were formed by just a few individuals each, which showed morphological variation regarding the isthmus, being more (fig. 5) or less (fig. 4) delimited, and also regarding the shape of the upper margin of semicell. In the first case (fig. 5), the isthmus is very well marked due to the basal margins of both semicells forming a more or less straight angle. In the second case (fig. 4), such an angle does not exist and the isthmus is not that much delimited, the sinus being just a curved, concave line that goes from the spine-bearing angle of one semicell to that of the opposite semicell. There is also variation in what respects the degree of curvature of the upper margin of semicells, which may be either shallower (fig. 5) or deeper (fig. 4).

\section{Octacanthium mucronulatum (Nordstedt) Compère var. mucronulatum}

Nova Hedwigia 112: 505, fig. 8-9. 1996.(Fig. 6-13)

Basionym: Arthrodesmus mucronulatus Nordst., Vidensk. Meddr dansk naturh. Foren. Kjøbenhavn 1869(14-15): 232. 1869; 1887: pl. 4, fig. 58. 1887.

Synonyms: Arthrodesmus mucronulatus Nordst. f. Borge, Ark. Bot. 1: 102, pl. 3, fig. 36. 1903.

Arthrodesmus mucronulatus Nordst.; Borge, Ark. Bot. 19(17): 36. 1925; Grönbl., Acta Soc. Sci. fenn.: ser. B, 2(6): 23, fig. 179. 1945; C. Bic., Phycologia 14(3): 145, fig. 1-9. 1975. 
Arthrodesmus convergens Ehr. f. Först., Hydrobiologia 23(3-4): 408, pl. 25, fig. 10. 1964.

Arthrodesmus hiatus Turn. f. pentangularis Först., Hydrobiologia 23(3-4): 408, pl. 25, fig. 11, pl. 48, fig. 3. 1964.

Cells 0.2-0.7 times broader than long without spines, deeply constrict at the mid-region; semicells elliptic-fusiform to hexagonal, upper margin variably convex, basal margin more or less angular, upper and lower angles with 1 short spine, upper ones usually mucronulate, sinus open, acute angled; cell wall hyaline, apparently smooth to finely punctate; apical view of semicell elliptic-fusiform, 1 sharp, short spine on each pole; chloroplasts furcoid, 2-centric. Measurements: cell length 22-38 $\mu \mathrm{m}$, cell breadth (with spines) $30-52.3 \mu \mathrm{m}$, (without spines) $24-46.3 \mu \mathrm{m}$, breadth of isthmus 8-17.5 $\mu \mathrm{m}$.

In literature: Aparecida, Arealva, Jaraçatiá, Moji Guaçu, Pinhal, Pontes Gestal, Registro, Ribeirão Preto, Sumaré, São Carlos (Bicudo \& Azevedo, 1977: 36, as Arthrodesmus mucronulatus Nordst. var. mucronulatus); Mococa, Tambaú (Bicudo, 1975: 145, as Arthrodesmus mucronulatus Nordst. var. mucronulatus; Bicudo \& Azevedo, 1977: 36, as Arthrodesmus mucronulatus Nordst. var. mucronulatus).

Material studied in the following sample units: SP336350, SP336343, SP336344, SP336345, SP188219, and SP239097.

The material used for the original description of Arthrodesmus mucronulatus Nordst. is Brazilian and was collected by Eugene Warming near by the town of Lagoa Santa, in the state of Minas Gerais, southeastern Brazil. According to its original description, A. mucronulatus has a short, simple spine tipping each lower angle of semicells and just a mucron at each upper angle (Nordstedt, 1869: 232). The original illustration of this species was published 17 years later (Nordstedt, 1887: pl. 4, fig. 58), together with all other illustrations of the 1869 paper and a few corrections to some figure captions.

Octacanthium mucronulatum (Nordst.) Comp. is a very polymorphic species. Strengthening Bicudo (1975), Bicudo \& Azevedo (1977) observed great morphological variation within the species in the three sample units studied. Latter authors observed some specimens with a supernumerary spine on each side of semicell, contiguous and immediately below the regular spine of the upper angle, some other specimens with no spine at the upper angles in spite of the persistent angular projection at the place formerly occupied by the spine, and a few specimens in which there was a disappearance of both the spine usually located at the upper angles of semicells and the angular projection, resulting in an uniformly convex upper margin. In a very extreme condition, Bicudo \& Azevedo (1977) observed the complete lack of the spines of the lower angles of the semicells. Specimens with spines only at the lower angles of both semicells and upper margin of semicells broad and uniformly convex, could be easily taken for Staurodesmus convergens (Ehr. ex Ralfs) Teil.

Populations studied from Itatinga, Paraguaçu Paulista, Pitangueiras, Rio Claro, and São Paulo also showed considerable morphological variation, mainly in what concerns the lack of the spines of the upper angles of semicells (fig. 1012) or the presence of supernumerary spines on the upper (fig. 9) and lower (fig. 9) angles of semicells. Also observed was the smoothing of the upper angle of semicells (fig. 11, 13) and the presence of an uniformly convex upper margin (fig. 13) which gives imperceptible continuation to the spines of the lower (now the only ones) angles of semicells.

\section{Octacanthium octocorne (Ralfs) Compère var. octocorne}

Nova Hedwigia 112: 503, fig. 3. 1996.(Fig. 2-3)

Basionym: Xanthidium octocorne Ralfs, Brit Desmidieae. 116, pl. 20, fig. 2a-e. 1848.

Synonyms: Arthrodesmus octocornis (Ralfs) Arch. in Pritch., Infusoria. 736, pl. 1, fig. 30. 1861.

Arthrodesmus octocornis Ehr.; Krieg., Ber. dt. bot. Ges. 63(2): 41. 1950.

Cells ca. 1.3 times longer than broad without spines, deeply constricted at the mid-region; semicells subtrapeziform to subhexagonal, upper and basal margins slightly concave, angles slightly rounded, tipped with 1 simple, straight spine, sinus broad, more or less circular; cell wall hyaline, smooth; apical view of semicell elliptic, 1 simple, straight spine on each rounded angle; chloroplasts and pyrenoids not observed. Zygospores globose to subglobose, furnished with a few, simple, straight spines, 8 of which are shown at the periphery; zygospore wall forming 1 thickening at the base of each spine. Measurements: cell length (with spines) 28-30 $\mu \mathrm{m}$, (without spines) 16-18 $\mu \mathrm{m}$, breadth (with spines) 24-25 $\mu \mathrm{m}$, (without spines) 11-12 $\mu \mathrm{m}$, breadth of isthmus ca. $5 \mu \mathrm{m}$; zygospores: diameter 25 $32 \mu \mathrm{m}$ (with spines), 14-17 $\mu \mathrm{m}$ (without spines).

In literature: Pirassununga (Borge, 1918: 40, as Arthrodesmus octocornis Ehr.); Atibaia, Lorena, São Paulo (Bicudo \& Azevedo, 1977: 36, as Arthrodesmus octocornis Ehr. ex Arch. var. octocornis).

Material studied in the following sample units: SP188207 and SP336347.

Despite its worldwide geographical distribution, the species displays a rather small form variation. According to the literature, such a variation refers to the curvature of the upper and basal margins of semicells, the prominence of the spiny angles, the orientation and size of the angle spines, and to the lack of the spines of the lower angles of semicells. 
Material from the state of São Paulo showed variation mainly of the isthmus, which was sometimes long and very much cylindrical (fig. 3) and some other times short and almost not cylindrical (fig. 2). It is also important to note the little metrical variation detected by Bicudo \& Azevedo (1977) in the three populations they studied and which were collected from three different localities (Atibaia, Lorena, and São Paulo) in the state of São Paulo.

Material from the municipality of São Paulo, collected from a display of aquatic plants at the São Paulo Botanical Gardens, presented frequently zygospores.

\section{CONCLUSIONS}

The floristic survey of genus Octacanthium of the state of São Paulo allowed us to draw the following conclusions:

1.Identification of 3 taxa of Octacanthium [O. bifidum (Bréb.) Comp. var. bifidum as Arthrodesmus bifidus Bréb. and Xanthidium bifidum (Bréb.) Defl. var. bifidum, $O$. octocorne (Ralfs) Comp. as Arthrodesmus octocornis (Ralfs) Arch. and Xanthidium octocorne Ralfs, and $O$. mucronulatum (Nordst.) Comp. as Arthrodesmus mucronulatus Nordst.].

2.Octacanthium mucronulatum (Nordst.) Comp. is the species that presented the broadest geographical distribution in the state, occurring in 5 different municipalities.

3. Sexual reproduction was observed just once in Octacanthium octocorne (Ralfs) Comp. var. octocorne. This reinforces the statement that sexuality is of rare occurrence in nature in the Desmidiaceae.

4.The fairly great metric variability observed both in the material studied and in the literature proved the impossibility of using just measurements for identification of species and infraspecific taxa in the genus. Due to the high incidence of polymorphism mainly in Octacanthium mucronulatum (Nordst.) Comp., it is nearly impossible to precisely identify anomalous specimens of this species without a very careful population analysis. Polymorphism hides which characteristics are good for diagnosis and which ones are not. Consequently, a robust identification depends on a very cautious study of the greatest possible number of specimens.

\section{ACKNOWLEDGEMENTS}

Senior author is very grateful to FAPESP, Fundação de Amparo à Pesquisa do Estado de São Paulo, for scholarship (Grant no 99/07388-5); and junior author to CNPq, Conselho Nacional de Desenvolvimento Científico e Tecnológico (Grant n ${ }^{\circ}$ 304643/90-4) and FAPESP, Fundação de Amparo à Pesquisa do Estado de São Paulo (Grant nº 98/
04955-3) for partial financial support of research.

\section{REFERENCES CITED}

Bicudo, C.E.M. 1975. Polymorphism in the desmid Arthrodesmus mucronulatus and its taxonomic implications. Phycologia 14(3): 145-148, fig.1-9.

Bicudo, C.E.M. \& Azevedo, M.T.P. 1977. Desmidioflórula paulista, 1: gênero Arthrodesmus Ehr. ex Ralfs emend. Arch. Biblthca phycol. 36: 1-105, fig. 1-73.

Borge, O. 1918. Die von Dr. A. Löfgren in São Paulo gessammelten Süsswasseralgen. Ark. Bot. 15(13): 1-108, pl. 1-8.

Compère, P. 1996. Octacanthium (Hansgirg) Compère, a new generic name in the Desmidiaceae. Nova Hedwigia supl. 112: 501-507, fig. 1-11.

Ehrenberg, C.G. 1836. Synonyme zur Corda's Infusorien. Arch. Naturgesch. Berlin 2:185.

Ehrenberg, C.G. 1838. Die Infusionsthierchen als volkommene Organismen: ein Blick in das tiefere Leben der Natur. Leopold Voss, Leipzig: Verlag von Leopold Voss. xxii + 1-547 p., pl. 1-64.

Marinho, M.M. \& Sophia, M.G. 1997. Desmidioflórula do Açude do Jacaré, Município de Mogi-Guaçu, SP, Brasil. Hoehnea 24(1): 37-53, fig. 1-57, tab. 1.

Nordstedt, C.F.O. 1869. 18 Fam. Desmidiaceae. In: Warming, E. (ed.) Symbolae ad floram Brasiliae centralis cognoscendam. Vidensk. Meddr dansk naturh. Foren. Kjöbenhavn 1869(14-15): 195-234.

Nordstedt, C.F.O. 1887. 18 Fam. Desmidiaceae. In: Warming, E. (ed.) Symbolae ad floram Brasiliae centralis cognoscendam. Vidensk. Meddr dansk naturh. Foren. Kjöbenhavn 1887: 233-234, pl. 2-4.

Ralfs, J. 1848. The British Desmidieae. London: Reeve, Benham and Reeve. P. xxii + 1-226, pl. 1-35.

Title: Genus Octacanthium (zygnemaphyceae, desmidiaceae) in the state of São Paulo, Brazil

Authors: Sílvia Maria Mathes Faustino \& Carlos E. de M. Bicudo

Biota Neotropica, Vol. 3 (number 1): 2003

http://www.biotaneotropica.org.br/v3n $1 / \mathrm{pt} /$ abstract?article+BN00303012003

Date Received 01/05/2003 Revised 02/15/2003

Accepted 03/07/2003

ISSN 1676-0611 